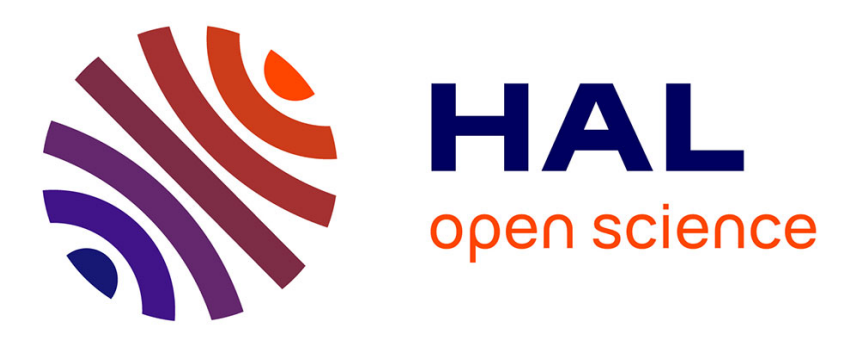

\title{
Tariff protection elimination and Common Agricultural Policy reform : implications of changes in methods of import demand modelling
}

\author{
Alexandre Gohin, Herve Guyomard, Chantal Le Mouël
}

\section{To cite this version:}

Alexandre Gohin, Herve Guyomard, Chantal Le Mouël. Tariff protection elimination and Common Agricultural Policy reform: implications of changes in methods of import demand modelling. 2002. hal-01931584

\author{
HAL Id: hal-01931584 \\ https://hal.science/hal-01931584
}

Preprint submitted on 22 Nov 2018

HAL is a multi-disciplinary open access archive for the deposit and dissemination of scientific research documents, whether they are published or not. The documents may come from teaching and research institutions in France or abroad, or from public or private research centers.
L'archive ouverte pluridisciplinaire HAL, est destinée au dépôt et à la diffusion de documents scientifiques de niveau recherche, publiés ou non, émanant des établissements d'enseignement et de recherche français ou étrangers, des laboratoires publics ou privés. 


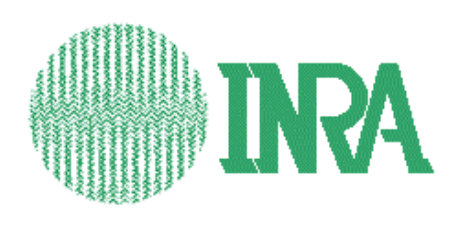

Institut National de la recherche Agronomique

Unité d'Economie et Sociologie Rurales

4 Allée Adolphe Bobierre, CS 61103

F 35011 Rennes Cedex

Tél. (33) 02234853 82/53 88 - Fax (33) 0223485380

http://www.rennes.inra.fr/economie/index.htm

Tariff protection elimination and Common Agricultural Policy reform:

Implications of changes in methods of import demand modelling

Alexandre GOHIN, Hervé GUYOMARD and Chantal LE MOUËL

March 2002

Working Paper 02-01 
Tariff protection elimination and Common Agricultural Policy reform: Implications of changes in methods of import demand modelling

Alexandre GOHIN, Hervé GUYOMARD and Chantal LE MOUËL INRA - ESR Rennes

\section{Corresponding address}

Hervé GUYOMARD

INRA - Unité ESR

4 Allée Bobierre, CS 61103

35011 Rennes Cédex, France

Email: hguyomar@roazhon.inra.fr 


\begin{abstract}
We show how to accommodate the traditional Armington assumption to capture the possibility for a country to import imperfect substitutes as well as perfect substitutes for domestically produced goods. When this possibility is incorporated into a modelling framework, then a Common Agricultural Policy (CAP) elimination scenario, including the setting to zero of import tariffs, would have starker implications than many studies suggest. To illustrate this point, we use a Computable General Equilibrium (CGE) model of the French economy highlighting agricultural and food sectors. We analyse the consequences for the French economy of a complete liberalisation scenario in the European sector of cereals.
\end{abstract}

Keywords: Armington, CGE, modelling, CAP

JEL classification: Q17, Q18, D58, C52

\title{
Résumé
}

Cet article propose une adaptation à la modélisation Armington usuelle, dont l'objet est de représenter la possibilité pour un pays d'importer des biens imparfaitement et/ou parfaitement substituables aux biens produits sur le territoire national. Nous montrons que les conséquences d'un scénario d'abandon de la Politique Agricole Commune (PAC) (y compris l'élimination de la protection tarifaire) seraient beaucoup plus importantes que ce que suggèrent nombre d'études existantes si cette possibilité était introduite dans les modèles de simulation utilisés. Pour illustrer ce point, nous utilisons un modèle d'Équilibre Général Calculable (EGC) de l'économie française, centré sur les secteurs agricole et agro-alimentaire. Nous simulons et analysons les conséquences pour l'économie française d'une libéralisation totale des secteurs européens des céréales.

Mots clé: Armington, EGC, modélisation, PAC

Classification JEL: Q17, Q18, D58, C52 


\title{
Tariff protection elimination and Common Agricultural Policy reform: Implications of changes in methods of import demand modelling
}

\author{
Alexandre GOHIN, Hervé GUYOMARD and Chantal LE MOUËL
}

\section{Introduction}

The basic provisions of the Uruguay Round Agreement on Agriculture (URAA) include reduction in domestic support, cuts in export subsidies and improvement in market access. It is now well admitted that tariffication of border measures and access provisions in the form of current access and minimum access tariff quotas have only marginally improved the competitiveness of imports into the European Union (EU) over the six-year implementation period of the URAA (e.g., Swinbank, 1999). The Agenda 2000 reform of the Common Agricultural Policy (CAP) has given a further advantage to the EU in the World Trade Organisation (WTO) talks of the Millennium Round (MR) on this dossier. By lowering intervention prices on cereals and beef, the Agenda 2000 reform would allow the EU to agree to significant tariff reductions without really challenging the so-called Community preference for these products. If tariff reductions are equal to intervention price cuts, tariffs will remain sufficiently high to still protect EU producers of cereals from imports with the exception of currently imported highquality cereals such as durum wheat, malting barley or high-quality common wheat.

In spite of this, the EU remains highly vulnerable on the market access front because world prices are still substantially lower than domestic prices for a large set of commodities (with the noteworthy exception of common wheat). As a result, many exporters are likely to significantly penetrate the EU market if protection is sufficiently reduced with the result that foreign products will be competitive relative to domestic products. However, most simulation studies concur that a unilateral or multilateral liberalisation policy would not represent a very grave threat to EU farmers. This is particularly the case for analyses based on Computable General Equilibrium (CGE) models (Harrison et al., 1995; Frohberg et al., 1990; Burniaux et al., 1990; Martin et al., 1990; Hubbard, 1994). For example, Harrison et al. find that a complete elimination of 
the CAP would result in a decrease in EU agricultural output ranging only from -2.2 per cent to -3 per cent according to assumptions made on capital mobility and wage flexibility.

In CGE models, it is typical to assume product differentiation between domestic and traded goods to capture stylised facts such as imperfect transmission of world price changes to domestic prices, incomplete specialisation and two-way trade (e.g., Weyerbrock, 1998). On the import side, the standard approach consists in specifying a Constant Elasticity of Substitution (CES) import aggregation function between commodities produced abroad and commodities produced domestically. ${ }^{1}$ The CES parametric form generates import demand functions with unitary expenditure elasticities which may yield unrealistic terms-of-trade and trade-volume effects when there are significant income effects (Robinson et al., 1992). ${ }^{2}$ Furthermore, if import shares in domestic consumption are initially very small, impacts of a tariff cut scenario on imported volumes, resource movement and welfare are likely to be underestimated (Morkre and Tarr, 1995).

One immediate solution to this second problem is to maintain the Armington assumption while using elasticities that are rather high by the usual standards (Morkre and Tarr, 1995; Gehlar, 1994; Anderson et al., 1999). But in the context of a tariff elimination scenario on agricultural imports into the EU, such an approach suffers from two main drawbacks. Firstly, there is the problem of parameter calibration since augmented Armington elasticities cannot be related to econometric work in the literature. As a result, calibration can only be very ad hoc even if Systematic Sensitivity Analyses (SSA) can be used as a partial palliative to this problem (Hertel, 1999). Secondly, the traditional Armington approach does not allow CGE (as well as partial) agricultural models to reproduce the fact that non differentiated agricultural imports are likely to penetrate the EU market in a regime where tariff protection is significantly reduced, at the extreme set to zero. In the case of wheat for example, a reduced tariff protection scenario would expose the EU to the prospect of increased imports of high-

\footnotetext{
${ }^{1}$ On the export side, the standard approach consists in specifying a Constant Elasticity of Transformation (CET) function between domestically produced goods for sale on the domestic market and domestically produced goods for sale on the export market.

${ }^{2}$ On this point, see also Brown (1987) who argues that the monopoly power implicit in product differentiation is the source of the strong terms-of-trade effects observed in Armington-type models.
} 
quality wheat, e.g., US Hard Red Winter or Canadian Western Red Spring, as well as cheaper and lower quality wheat (USDA, 1999). Under the current CAP, imports of relatively lower quality wheat are null because the restrictive border measures prevent imports of commodities that are very substitutable for domestically produced goods.

In that context, the objective of the paper is twofold. Firstly, we show how to accommodate the traditional Armington assumption to capture the possibility for a country to import imperfect substitutes as well as perfect substitutes for domestically produced goods. Secondly, we show that when this possibility is incorporated into a modelling framework, then a CAP elimination scenario, including the setting to zero of import tariffs, would have starker implications than the above mentioned studies suggest. To that purpose, we use a CGE model of the French economy highlighting agricultural and food sectors and we analyse the consequences of a complete liberalisation scenario in the French sector of cereals. ${ }^{3}$

The remainder of the paper has five sections. Section 2 provides an overview of the CGE model. Section 3 gives a detailed description of the trade specification adopted for cereals. Section 4 describes the reform experiments. Section 5 analyses the results and Section 6 concludes.

\section{Model overview}

The structure of the model is outlined in Annex 1. It is a static, agriculture and agrifood focused CGE model of the French economy benchmarked to data for 1990. The two foreign regions, i.e., the Rest of the European Union (RoEU) and the Rest of the World (RoW), are incorporated in a reduced manner as they are simply entered as suppliers of French imports and demanders of French exports. The model is neoclassical and Walrasian in spirit, in the tradition of Shoven and Whalley (1984).

The model identifies nine agricultural industries, six food processing industries, five industries for the rest of the economy and two retailing industries. The nine agricultural industries produce fourteen agricultural products and the six food processing industries produce eleven food products. The industry and product disaggregation of the model is reported in Annex 2. The disaggregation level on the production side is sufficiently

\footnotetext{
${ }^{3}$ In practice, the liberalisation scenario applies to cereals (wheat, maize, barley and other cereals), oilseeds (rapeseed, sunflower, soya and linseed) and protein crops (peas, beans and lupins) in so far as the provision for support to these three categories of products is provided for within the same scheme, i.e., the Arable Area Payments Scheme (AAPS). For more details, see Section 4.
} 
detailed to capture the main forward and backward linkages among the various agricultural industries, as well as between the agricultural industries, the food processing industries and the raw material suppliers. It facilitates agricultural production technology modelling where substitution among intermediate inputs, as well as between intermediate inputs and primary factors of production, plays a crucial role. In addition, it allows us to accurately represent the working of main CAP instruments.

Production technologies are constant returns to scale. They are modelled by means of nested CES input production functions and CET product transformation functions. Production is disposed of on domestic and foreign markets. Producers maximise revenue from sales subject to a CET transformation function. The first-order conditions of this programme determine export supplies as a function of relative prices and the elasticities of transformation between goods sold on the domestic and the two export markets. Domestic and imported goods are also distinct with separate sectoral prices. Consumers demand a composite good which is a CES aggregate of domestic goods, imports from the RoEU and imports from the RoW. Given the first-order conditions, import demands are functions of relative prices and the elasticities of substitution between goods purchased on the domestic and the two import markets. The CET-CES treatment of exports and imports is now very common in CGE models, essentially because of its tractability. In the next section, we show how to accommodate this specification to capture the fact that in a regime without tariff protection on cereals, France (more generally the EU) is likely to import differentiated as well as undifferentiated cereals.

With respect to the RoEU, France is assumed to be a large country for all products on both the import and export side. As a result, French exporters to the RoEU face a downward-sloping demand curve and French importers from the RoEU face an upwardsloping supply curve. With respect to the RoW, France is modelled as a small open economy on both the import and export side with the exception of cereals and dairy products.

The resource endowment of the economy consists of a fixed supply of the three primary inputs, i.e., labour, capital and land. Labour and capital are assumed to be imperfectly mobile between the three industry aggregates, i.e., agriculture, the food processing industries and the rest of economy. They are perfectly mobile across industries belonging to a given aggregate. Land is used in agriculture only. It is assumed to be 
imperfectly mobile between the three agricultural subaggregates corresponding to COP crops (cereals, oilseeds and protein crops), livestock products and other agricultural products. It is perfectly mobile across products belonging to a given agricultural subaggregate. ${ }^{4}$ Production quotas are modelled as a fourth primary factor of production which ensures that the zero-profit condition holds in sectors controlled by quotas (Hertel and Tsigas, 1991).

The four components of domestic demand are intermediate demand, final private consumption, French government demand and investment. There is one representative household which saves a fixed proportion of its disposable income. The latter is defined as the sum of rental income from capital, land and production quotas, wage income from labour and transfer income from the French government, the European Agricultural Guidance and Guarantee Fund (EAGGF) and the two foreign zones, after deduction of personal income taxes and transfers to the RoEU and the RoW. The household's commodity demands are derived by constrained maximisation of a nested Stone-Geary utility function.

The French government is modelled as an explicit, but non-optimising agent. It saves a fixed proportion of its disposable income defined as the sum of rental income from primary factors of production that it owns (i.e., capital and land), income transfers withdrawn from the domestic household and the two foreign zones, tariffs on imports, ad valorem taxes on production and ad valorem taxes on private consumption. It uses this income to save and for subsidy expenditures, transfer payments to the domestic household and the two foreign zones, as well as public consumption in services. Nominal government demand in services is set exogenously. The French government budget is balanced through transfers to/from the domestic household and the RoEU.

The EAGGF is modelled in a simplified way. It pays all input, output and export subsidies corresponding to CAP expenditures. Its budget is balanced through income transfers from the RoEU. Its working can be illustrated as follows. Let us assume that direct aid payments to French farmers are reduced by a given amount. In that case, transfers from the RoEU to the EAGGF are reduced by the same amount to balance the

\footnotetext{
${ }^{4}$ The degree of imperfect mobility of a primary input is captured by the elasticity of transformation of a CET function. Following Peerlings (1993), we assume that this parameter equals 0.1 for land, 0.3 for labour and 0.5 for capital.
} 
EAGGF budget. Transfers from the French government to the RoEU are also diminished by the same amount, and budgetary economies are redistributed to the domestic household by increasing transfers from the French government to the domestic household.

The model is solved in a neoclassical way. Investment is savings driven. It is equal to total available savings defined as the sum of private savings, French government savings and foreign savings. The balance of payments with respect to the RoEU is balanced through the domestic deficit/surplus relative to this foreign zone. The exchange rate with respect to the RoEU is thus fixed. The balance of payments with respect to the RoW is constrained by an externally defined deficit level. The model is thus solved for the real equilibrium exchange rate with respect to the RoW.

Agricultural trade policies and internal farm programmes are modelled explicitly, including import tariffs, variable export subsidies, input and output subsidies, production quotas, the intervention price mechanism and the mandatory set-aside programme. $^{5}$

\section{Agricultural policy modelling and trade specification for cereals}

The basic elements of the EU legislation applied to cereals include public purchases at minimum intervention prices, export subsidies and protection against imports through tariffs. $^{6}$ The internal support mechanism combines price support with direct area payments. Producers of COP crops get the direct aids only if they set aside part of their land. The mandatory set-aside rate is fixed annually and compensation for set aside is paid per hectare.

\subsection{Intervention mechanism modelling and export specification}

The intervention price is a political price set exogenously. It is the delivered to store price at which EU purchases, through national boards, are made. In practice, intervention buying serves to maintain EU market prices at a minimum level in a regime where domestic supply exceeds internal demand. We assume that French cereals that are initially purchased for public storage can be disposed of on the French market,

\footnotetext{
${ }^{5}$ The voluntary set-aside programme is not modelled.

${ }^{6}$ Before the URAA, protection was ensured through threshold prices and variable import levies. Under the URAA, the threshold prices were abolished and the import levies were converted into specific duties. In the case of cereals in the EU, the duty-paid price cannot exceed 155 per cent of the intervention price.
} 
exported to the RoEU market and/or exported to the RoW market through the use of variable export subsidies. The latter are intended to bridge the gap between French and world prices. ${ }^{7}$ We assume that domestically produced cereals for sale on the two export markets are perfect substitutes for domestically produced cereals for sale on the French market. This assumption is more realistic than the alternative of imperfect substitutability because the intervention mechanism largely prevents French farmers from differentiating production according to destination markets in a regime of excess supply.

The perfect substitutability assumption implies that the standard CET export aggregation function used for products which are not regulated by the intervention mechanism is here replaced by a simple sum and that equilibrium prices of domestic sales, exports to the RoEU and exports to the RoW are equal, i.e., ${ }^{8}$

$$
\begin{aligned}
& Y=Y D+E_{R o E U}+E_{R o W} \\
& P=P D=P E_{\text {RoEU }}=P E_{R o W}
\end{aligned}
$$

where $Y$ is the domestic production with price $P, Y D$ is the domestically produced quantity sold on the French market with price $P D, E_{R o E U}$ are exports to the RoEU with price $P E_{R o E U}$, and $E_{R o W}$ are exports to the RoW with price $P E_{R o W}$.

To accommodate the intervention price regime $(P=P I$, where $P I$ is the intervention price) and the competitive price regime $(P>P I)$ simultaneously, we use the mixedcomplementarity approach (Rutherford, 1995; Löfgren and Robinson, 1997) by specifying a set of inequalities-equalities:

$$
P \geq P I
$$

$$
S .(P-P I)=0
$$

The price regime is endogenously determined. When export subsidies $S$ are strictly positive, the market price $P$ is equal to the intervention price (equation $3 \mathrm{~b}$ ). The latter is strictly greater than the world export price in French francs $\left(P W E_{R o W} . E R_{R o W}\right.$, where

\footnotetext{
${ }^{7}$ Export subsidies are granted in the light of market situations. As a result, the subsidy can be a tax if world prices are greater than EU prices. Following Weyerbrock (1998), we do not allow for agricultural export taxes because we think that the EU is not able to defend export taxes over an extended period. In practice, we will assume that EU market prices cannot be lower than world prices.

${ }^{8}$ To simplify notation, we drop the $i$ subscript corresponding to the type of cereals ( 1 for common wheat, 2 for barley, 3 for maize and 4 for other cereals).
} 
$P W E_{R o W}$ is the world export price in world currencies and $E R_{R o W}$ is the exchange rate with respect to the RoW), and the ad valorem export subsidy $s$ covers the difference according to the following equation:

$P I=P=P W E_{R o W} \cdot E R_{R o W} \cdot(1+s)$

When export subsidies equal zero, the market price $P$ is greater than or equal to the intervention price $P I$ (equation 3a). This arises when the ad valorem export subsidy s is null (in that case $P=P W E_{R o W} . E R_{R o W}$ ) and/or when exports to the RoW equal zero.

\subsection{Import specification: the modified Armington specification}

On the import side, consumers demand a composite good which is a CES aggregate of imports from the RoW, imports from the RoEU and commodities produced domestically. Given the first-order conditions, the import demand function from a given foreign zone is defined as a function of the relative price of the composite good to the relevant import price, the elasticity of substitution between the three sources, as well as the shift and share parameters in the CES function. This is the traditional Armington specification adopted here for all tradable commodities including cereals in the two benchmark experiments, i.e., experiments 1 and 2 in Section 4. In experiment 3, this specification is modified for cereals to allow France to import differentiated (i.e., imperfectly substitutable) and undifferentiated (i.e., perfectly substitutable) cereals from the RoW in a scenario where tariff protection on cereals from the RoW is set to zero. The modified CES import aggregation function is defined by:

$X C=\alpha \cdot\left(\delta \cdot\left(Y D+S M_{R o W}\right)^{-\rho}+\delta_{R o W} \cdot M_{R o W}^{-\rho}+\delta_{R o E U} \cdot M_{R o E U}^{-\rho}\right)^{-(1 / \rho)}$

where $X C$ is the composite commodity, $S M_{R o W}$ are French imports from the RoW that are perfectly substitutable for French cereals, $M_{\text {RoW }}$ are French imports from the RoW that are imperfectly substitutable for French cereals, $M_{R o E U}$ are French imports from the RoEU, and $\alpha, \delta, \delta_{R o W}, \delta_{R o E U}$ and $\rho$ are parameters.

The program of minimising the cost of purchasing a given quantity of the composite good may be written as:

$\min _{Y D, S M_{R o W}, M_{R o W}, M_{R o E U}} P D . Y D+P S M_{R o W} \cdot S M_{R o W}+P M_{R o W} \cdot M_{R o W}+P M_{R o E U} \cdot M_{R o E U}$

subject to (5) 
where $P S M_{R o W}$ is the import price of perfectly substitutable imports from the RoW, $P M_{R o W}$ is the import price of imperfectly substitutable imports from the RoW, and $P M_{R o E U}$ is the import price of imports from the RoEU.

By rearranging the first-order conditions of the minimisation programme (6), we get:

$$
\begin{aligned}
& M_{j}=\alpha^{\sigma-1} \cdot X C \cdot\left(\delta_{j} \cdot \frac{P C}{P M_{j}}\right)^{\sigma} \quad j=R o W, R o E U \\
& Y D+S M_{R o W}=\alpha^{\sigma-1} \cdot X C \cdot\left(\delta \cdot \frac{P C}{P D S M}\right)^{\sigma}
\end{aligned}
$$

with

$$
\begin{aligned}
& P C=(1 / \alpha) \cdot\left(\delta^{\sigma} \cdot P D S M^{1-\sigma}+\delta_{R o W}^{\sigma} \cdot P M_{R o W}^{1-\sigma}+\delta_{R o E U}^{\sigma} \cdot P M_{R o E U}^{1-\sigma}\right)^{\frac{1}{1-\sigma}} \\
& P M_{j}=P W M_{j} \cdot E R_{j} \cdot\left(1+t_{j}\right) \quad j=R o W, R o E U \\
& P S M_{R o W}=P W S M_{R o W} \cdot E R_{R o W} \cdot\left(1+s t_{R o W}\right) \\
& P D S M=\min \left(P D, P S M_{R o W}\right)
\end{aligned}
$$

where PC is the CES price index of the composite good $\mathrm{XC}, P W M_{j}$ is the price of imperfectly substitutable imports from region $j$ in world $(j=\mathrm{RoW})$ or European $(j=\mathrm{RoEU})$ currencies, $t_{j}$ is the ad valorem tariff applied on imperfectly substitutable imports from region $j, P W S M_{R o W}$ is the price of perfectly substitutable imports from the RoW in world currencies, and $s t_{R o W}$ is the ad valorem equivalent tariff applied on perfectly substitutable imports from the RoW.

Equation (7a) defines the import demand functions for imperfectly substitutable cereals from the RoW and the RoEU. They correspond to traditional Armington specifications. The import demand function for imperfectly substitutable cereals from a foreign region $j$ depends on the quantity of the composite commodity $(\mathrm{XC})$, the domestic price relative to import price $\left(P C / P M_{j}\right)$, the elasticity of substitution $(\sigma)$, as well as the shift and share parameters in the CES function ( $\alpha$ and $\delta_{j}$ ). Removal of tariffs on imperfectly substitutable imports from the RoW decreases the import price $P M_{R o W}$ and increases

\footnotetext{
${ }^{9}$ With $t_{\text {RoEU }}=0$.
} 
imperfectly substitutable imports from this foreign zone according to the share weight $\delta_{\text {RoW }}$, ceteris paribus.

Equation (7b) defines the demand function for the linear aggregate of domestically produced cereals and perfectly substitutable imports from the RoW. Equation (8d) defines the price of this aggregate. In a regime where the import price $P S M_{R o W}$ is strictly greater than the domestic price PD, France will not import cereals from the RoW that are perfect substitutes for domestically produced cereals. This corresponds to both the reference year situation (1990) and the current regime where tariff protection is still very high. But in a regime where the import price $P S M_{R o W}$ equals the domestic price PD, France will simultaneously import perfectly substitutable cereals and sell domestically produced cereals on its domestic market. This can arise in a situation where tariff protection on cereals imported from the RoW is suppressed. Finally, when the import price $P S M_{R o W}$ is strictly lower than the domestic price PD, domestic sales of French cereals will vanish. These three equilibrium conditions can be summarised as follows:

$$
\begin{aligned}
& S M_{\text {RoW }}=0 \text { and } Y D>0 \text { when } P S M_{R o W}>P D \\
& S M_{\text {RoW }} \geq 0 \text { and } Y D \geq 0 \text { when } P S M_{R o W}=P D \\
& S M_{R o W}>0 \text { and } Y D=0 \text { when } P S M_{R o W}<P D
\end{aligned}
$$

\section{The experiments}

Table 1 details the three experiments. All assume a removal of internal support measures in force in the sector of cereals as well as of export subsidies on cereal exports to the RoW. ${ }^{10}$ In experiment 1, import tariffs on cereal imports from the RoW are maintained at base period levels. In experiments 2 and 3, they are set to zero. In experiments 1 and 2, cereal imports are modelled using the traditional Armington specification. In experiment 3, they are modelled using the modified Armington specification. At this stage, the following remark is in order.

The CGE model used in this paper focuses on France, the RoEU being simply entered

\footnotetext{
${ }^{10}$ The three liberalisation experiments apply to all COP crops. For oilseeds and protein crops, there are no import duties and exports do not qualify to subsidies. In addition, there is no system of intervention and the support is given only through direct aids. In the three experiments, these direct aids are set to zero. Note also that France and the RoEU are very large net importers of oilseeds in the base year.
} 
as a supplier of French imports and a demander of French exports. As a result, contemplated policy changes can be simulated explicitly only for France. But as we realistically consider that all experiments apply at the EU level (i.e., simultaneously in France and in the RoEU), impacts of policy changes in the RoEU must also be taken into account. This can be done only in an implicit way through induced effects of policy changes on RoEU import supplies and export demands. In all experiments, impacts of contemplated policy changes in the RoEU are taken into account by assuming that market price adjustments are identical (in percentage terms) in France and in the RoEU. Such an assumption implies notably that COP market equilibria are defined at the whole EU level.

(Table 1)

\section{The results}

We first analyse the consequences of the three experiments for the four cereals distinguished in the model, i.e., common wheat, barley, maize and other cereals (Table 2). In a second stage, we examine the impacts of the three experiments on selected variables (Table 3).

(Table 2 and Table 3)

\subsection{Impacts on cereals}

Experiment 1 leads to domestic price reductions for the four cereals, the production price of common wheat falling the most (-19.1 per cent with respect to the base), the production price of other cereals falling the least $(-4.3$ per cent). French exports of cereals to the RoW vanish in a regime where world export prices are lower than French (and EU) market prices and where there are no more export subsidies to bridge the price gap. French imports of RoW cereals that are perfectly substitutable for domestically produced cereals remain null due to the maintenance of import tariffs that prevent these imports to penetrate the French market. As expected, French imports of RoW cereals that are imperfectly substitutable for domestically produced cereals decrease. The declines are large in percentage (-64.5 per cent for common wheat), but modest in absolute terms (-44 million 1990 French Francs for common wheat) because import shares in domestic consumption are initially very small. The four cereals experience large decreases in domestic production (-21.3 per cent for common wheat, -14.2 per cent for barley, -9.1 per cent for maize and -12.6 per cent for other cereals). At this 
stage, it is useful to remind that there is no compensation for price cuts in this first experiment, as well as in the two other experiments.

In the first experiment where import tariffs on cereals from the RoW are maintained at base period levels, the French and EU price system remains largely isolated from world prices (in reality as well as in the model). Domestic prices are endogenous variables which ensure that the French and RoEU markets clear. Domestic price reductions differ across cereals mainly in function of initial shares of RoW exports to domestic supply: the higher the share, the greater the domestic price reduction.

On the domestic demand side, experiment 1 affects the four cereals very differently. The combined effects of unequal domestic price reductions result in different impacts on total domestic demand $(X C)$, domestic intermediate consumption $(C I T)$ and domestic sales of domestically produced cereals $(Y D)$. While total domestic demand for common wheat and barley increases by +5.5 per cent and +3.0 per cent, respectively, total domestic demand for maize remains almost unchanged $(+0.2$ per cent $)$ and total domestic demand for other cereals decreases (-1.4 per cent). ${ }^{11}$ The same pattern of changes is observed for domestic intermediate consumption and domestic sales of domestically produced cereals.

Let us now consider experiments 2 and 3 where import tariffs on cereals from the RoW are removed. Table 2 clearly highlights the crucial role of the method for modelling cereal imports from the RoW.

When retaining the traditional Armington approach, the removal of import tariffs on cereals from the RoW has nearly no effect on domestic cereal markets relative to experiment 1. This is not surprising. Base period cereal imports from the RoW and related levied tariffs are very small. ${ }^{12}$ Because the traditional Armington modelling of

\footnotetext{
${ }^{11}$ These outcomes may easily be explained by noting that the fall in own price causes demand to increase, but the fall in prices of substitutable crops causes demand to decrease. In the case of maize and other cereals, the negative cross-price effects offset the positive own-price and expansion effects so that total domestic demand remains nearly unchanged for maize and decreases for other cereals.

${ }^{12}$ In the 1990 reference year, French imports of cereals from the RoW were very low. Figures from the French National Accounts indicate that the share of these imports in total domestic demand was 0.36 per cent for common wheat, 0.01 per cent for barley, 5.35 per cent for maize and 1.72 per cent for other cereals. Moreover, related calculated ad valorem tariff equivalents were also very low: 3.03 per cent for common wheat, 0 per cent for barley, 1.54 per cent for maize and 1.61 per cent for other cereals. These figures suggest that cereals imported from the RoW are mainly imperfect substitutes for domestically produced ones, tariffs levied on these imports being much lower than corresponding URAA consolidated tariff equivalents, and these cereals entering the French market because they satisfy specific needs corresponding to demands for high quality cereals.
} 
imports does not allow a flow of perfectly substitutable cereal imports from the RoW to be generated, the French and EU price system remains thus, artificially, isolated from world prices even after tariff protection is removed. Relative to experiment 1, experiment 2 induces only a small reduction in cereal import tariffs initially applied on small quantities.

In contrast, the impact of removing cereal border protection on domestic markets is markedly different when the modified Armington specification is used. In experiment 3, imports of perfectly substitutable cereals from the RoW penetrate the French market in large quantities: 2,261 million French Francs for common wheat (11.8 per cent of total domestic demand), 2,143 million French Francs for barley (26.8 per cent of total domestic demand), 3,170 million French Francs for maize (41.8 per cent of total domestic demand) and 1,629 million French Francs for other cereals (39.5 per cent of total domestic demand).

In experiment 3, the French and RoEU price system is no longer isolated from world prices (in reality as well as in the model). Domestic price decreases are thus greater, in absolute value, in this third experiment relative to both experiments 1 and 2 . This is particularly the case for the three cereals which experienced relatively limited domestic price declines in experiments 1 and 2, i.e., barley, maize and other cereals. In the case of common wheat, domestic price decreases are almost equal in experiments 1 and $3(-19.1$ per cent and -20.1 per cent, respectively). Domestic production price reductions being more pronounced and more equally distributed among cereals, impacts of experiment 3 on domestic production are also more important and more equally distributed across cereals. With respect to the base, domestic production decreases by -32.9 per cent for common wheat, -34.4 per cent for barley, -33.6 per cent for maize and -39.7 per cent for other cereals.

The effects of experiment 3 on domestic intermediate consumption and total domestic demand are positive. Total domestic demand increases by very large percentages for maize $(+23.5$ per cent with respect to the base), other cereals $(+12.3$ per cent) and barley (+8.9 per cent). By contrast, total domestic demand for common wheat increases only by a small percentage $(+2.2$ per cent). For the four cereals, the augmented domestic demand is essentially satisfied by imports of perfectly substitutable cereals from the RoW. As a result, the four cereals experience very large decreases in domestic sales (- 
9.8 per cent for common wheat, -21.2 per cent for barley, -25.6 per cent for maize and 31.7 per cent for other cereals).

\subsection{Other impacts on selected variables}

Table 3 summarises the effects of the three experiments on selected variables. In a general way, changes are equivalent in experiments 1 and 2 and more pronounced in experiment 3 when the modified Armington specification is used. Once again, these results illustrate the key importance of the modelling of imports when analysing liberalisation policy scenarios. Indeed, results from experiment 3 show that removing the border protection on cereals would significantly affect all French (and RoEU) agricultural sectors.

In the three experiments, animal sectors benefit from price cuts in domestic cereal markets. In experiment 1 , pork and poultry domestic production increases by almost +2.5 per cent with respect to the base and beef domestic production expands by +6.8 per cent. Increases are similar in experiment 2. Because cereal price decreases are higher (in absolute value) in experiment 3 relative to both experiments 1 and 2, animal domestic production increases are also larger $(+5.3$ per cent for pork, +4.8 per cent for poultry and +12.1 per cent for beef). As expected, all experiments induce a large decrease in value added in the French sector of COP crops, the experienced decrease being much greater in experiment 3 ( -53.7 per cent relative to the base) than in the two other experiments (-35.2 per cent). At this stage, it is worth remembering again that price cuts are not compensated by direct payments. Our results suggest that very large compensatory payments would be necessary to maintain value added of COP crops at base period levels.

All experiments result in an overall economy-wide welfare gain with respect to the base. The Hicksian Equivalent Variation increases by nearly $+4,230$ million French Francs in experiments 1 and 2, and by $+2,427$ million French Francs in experiment 3. The latter is thus welfare worsening with respect to experiments 1 and 2 . This outcome may seem counterintuitive. In practice, it corresponds to a "second-best" result. In experiment 1, market distortions are reduced by eliminating all internal support measures for COP crops and by setting export subsidies for cereals to zero. In experiment 3 , tariff protection on cereals is simultaneously suppressed. Hence, market distortions in the sector of COP crops are theoretically more reduced in experiment 3 
relative to experiment 1 . However, in all experiments, all other support programmes (in particular those applied to beef and milk) are maintained unchanged. As a result, liberalising the sector of COP crops may lead to increased market distortions in other agricultural sectors. This is actually the case in all experiments, with market distortions in other sectors increasing more in experiment 3 relative to experiments 1 and 2.

\section{Concluding remarks}

In the EU (as well as in other countries where import tariffs are still very high), agricultural imports that are perfectly substitutable for domestically produced goods are null (at maximum, very low) only because of the restrictive tariff protection that prevent them to penetrate the EU market. The standard Armington assumption does not allow general (as well as partial) equilibrium agricultural models to reproduce the fact that differentiated as well as undifferentiated agricultural imports could penetrate the EU market in a regime where tariff protection is sufficiently reduced, at the extreme set to zero. The modified Armington modelling framework we propose is a possible solution to remedy this drawback. This is illustrated on the example of cereals in a Member State (France) using a CGE model of the French economy highlighting agricultural and food sectors. When using the traditional Armington specification, the removal of cereal tariff protection has nearly no effects on French cereal markets. In contrast, when using the proposed modified Armington specification, cereal markets as well as other agricultural sectors are substantially affected by the setting to zero of tariffs on cereal imports.

This paper illustrates, on the example of one commodity (cereals) in one EU Member State (France), to what extent impacts of liberalising EU agricultural markets and policies can be underestimated when using the traditional Armington approach for modelling imports. In the MR negotiation context, it shows that the crucial necessity for the EU (at least from an internal political point of view) to maintain a "sufficient" import protection will give leverage to other countries to obtain very binding commitments on both the internal support and export competition dossier. 


\section{References}

Anderson, K., Hoekman, B. and Strutt, A. (1999). Agriculture and the WTO: Next steps. Paper presented at the Second Annual Conference on Global Economic Analysis, Assens, Denmark.

Brown, D.K. (1987). Tariffs, the terms of trade, and national product differentiation. Journal of Policy Modelling, 9: 503-526.

Burniaux, J.M., Martin, J.P., Delorme, F., Lienert, I. and Van der Mensbrugghe, D. (1990). Effets macroéconomiques des politiques agricoles dans les pays de l'OCDE : une approche d'équilibre général utilisant le modèle WALRAS, in Libéralisation des Échanges agricoles : Implications pour les Pays en Développement, (Ed.) I. Goldin and O. Knudsen, OCDE, Paris, pp. 309-334.

Frohberg, K., Fischer, G. and Parikh, K.S. (1990). Les pays en développement profiteraient-ils d'une libéralisation des échanges agricoles au sein des pays de l'OCDE? in Libéralisation des Échanges agricoles : Implications pour les Pays en Développement, (Ed.) I Goldin and O Knudsen, OCDE, Paris, pp. 247-281.

Gehlar, M.J. (1994). Economic Growth and Trade in the Pacific Rim: An Analysis of Trade Patterns. Ph. Dissertation, Purdue University.

Harrison, G.W., Rutherford, T.F. and Wooton, I. (1995). Liberalizing agriculture in the European Union. Journal of Policy Modeling, 17: 223-255.

Hertel, T. (1999). Applied general equilibrium analysis of agricultural and resource economics. Working Paper 99-2, Department of Agricultural Economics, Purdue University.

Hertel, T. and Tsigas, M. (1991). General equilibrium analysis of supply control in US agriculture. European Review of Agricultural Economics, 18: 167-191.

Hubbard, L.J. (1994). General Equilibrium Analysis of Agricultural Policy and Trade Reform. Paper presented at the Annual Conference of the Agricultural Economics Association, University of Exeter.

Löfgren, H. and Robinson, S. (1997). The Mixed-Complementarity Approach to specifying Agricultural Supply in Computable General Equilibrium Models. Paper 
presented at the 23rd Conference of the International Association of Agricultural Economists, Sacramento.

Martin, J.P., Burniaux, J.M., Delorme, F., Lienert, I. and Van der Mensbrugghe, D. (1990). Economy-wide effects of agricultural policies in OECD countries: Simulation results with WALRAS. OECD Economic Studies, 13: 131-172.

Morkre, M. and Tarr, D. (1995). Reforming Hungarian agricultural trade policy: A quantitative evaluation, Welwirtschaftliches Archiv. Review of World Economics, 131: 106-131.

Peerlings, J. (1993). An Applied General Equilibrium Model for Dutch Agribusiness Policy Analysis. Ph. Dissertation, Wageningen University.

Robinson, S., Soule, M. and Weyerbrock, S. (1992). Import demand functions, trade volumes, and terms of trade effects in multi-country general equilibrium models. Working Paper, Department of Agricultural and Resource Economics, University of California.

Rutherford, T. (1995). Extensions of GAMS for complementarity problems arising in applied economic analysis. Journal of Economic Dynamics and Control, 19: 12991324.

Shoven, J.B. and Whalley, J. (1984). Applied general equilibrium models of taxation and international trade: An introductory survey. Journal of Economic Literature, 22: 1007-1051.

Swinbank, A. (1999). CAP reform and the WTO: Compatibility and developments. European Review of Agricultural Economics, 26: 389-407.

USDA (1999). Grains: World Markets and Trade. United States Department of Agriculture (USDA), Foreign Agricultural Service, Circular Series FG 4-99.

Weyerbrock, S. (1998). Reform of the European Union's common agricultural policy: how to reach GATT compatibility? European Economic Review, 42: 375-411. 


\section{Annex 1. General characteristics of the CGE model}

1. Single-country, multi-sector, static CGE model applied to France, benchmarked to data for 1990, focused on agricultural and food processing sectors.

2. Two foreign markets: the Rest of the European Union (RoEU) and the Rest of the World (RoW).

3. 22 multi-product activity sectors and 30 products: 9 agricultural sectors and 14 agricultural products, 6 food processing industries and 11 food products, 2 retailing sectors, and 5 mono-product activity sectors for the rest of the economy (for more details, see Annex 2).

4. Multi-stage, multi-product, constant-returns to scale production technologies with substitution between inputs, including intermediate inputs.

5. Imperfect substitution between domestic and foreign commodities on both the import and export side (Armington assumption), except for some "regulated" products (see text).

6. Small country assumption on both the import and export side with respect to the RoW, except for some agricultural and food products (cereals and dairy products); large country assumption on both the import and export side with respect to the RoEU for all products.

7. Four primary production factors: labour, capital, land and production rights (i.e., production quotas).

8. Imperfect mobility of primary production factors across activity sectors on the basis of nested CET functions.

9. Three institutional sectors: a single representative consumer, the French government and the European Agricultural Guidance and Guarantee Fund (commonly known under its French acronym FEOGA).

10. Multi-stage budgeting process for the single representative consumer and allocation of its disposal income on the basis of linear expenditure systems.

11. Explicit modelling of public policy instruments with special attention given to CAP instruments: intervention price mechanism, export subsidies, import tariffs, production quotas, direct payments, set aside, ...

12. Competitive markets and neoclassical macro-economic closure. 


\begin{tabular}{l} 
Industries Commodities \\
\hline
\end{tabular}

\section{Agriculture}

COP crops

Arable crop farming

Soft wheat, barley, maize, other cereals, oilseeds, protein crops

Livestock products

Dairy farming

Raw milk, cattle, fodder crops

Cattle farming

Cattle, fodder crops

Mixed farming

Raw milk, cattle, fodder crops

Other agricultural products

Viticulture

Wine

Other vegetal farming

Other vegetal products

Pig farming

Pigs

Poultry farming

Poultry and eggs

Other animal farming

Other animal products, fodder crops

\section{Food processing}

Meat industry

Bovine meat, pig meat, poultry meat, other meats

Dairy industry

Butter and skimmed milk powder, other dairy products

Compound feed industry

Compound feed

Cereal processing industry

Cereal processed products

Oilseed crushing industry

Oils, oilmeals

Other food product industry

Other food products

\section{Rest of the economy}

Fishery

Fertiliser industry

Pesticide industry

Other manufacturing

Services

Food retailing

Other trade
Fish, fish products

Fertilisers

Pesticides

Other manufacturing products

Services 
Table 1: Experiment design

\begin{tabular}{|c|c|c|c|}
\hline & Experiment 1 & Experiment 2 & Experiment 3 \\
\hline $\begin{array}{l}\text { Cereal import } \\
\text { specification }\end{array}$ & $\begin{array}{l}\text { Traditional Armington } \\
\text { specification }\end{array}$ & $\begin{array}{l}\text { Traditional Armington } \\
\text { specification }\end{array}$ & $\begin{array}{l}\text { Modified Armington } \\
\text { specification }\end{array}$ \\
\hline \multicolumn{4}{|l|}{ Assumptions on cereals } \\
\hline $\begin{array}{l}\text { - Domestic support } \\
\text { measures }\end{array}$ & Eliminated & Eliminated & Eliminated \\
\hline - Export subsidies & Eliminated & Eliminated & Eliminated \\
\hline - Import tariffs & $\begin{array}{l}\text { Maintained at base } \\
\text { period levels }\end{array}$ & Eliminated & Eliminated \\
\hline
\end{tabular}

Note: In the three experiments, all policy measures on oilseeds and protein crops are suppressed (see footnote 10). 
Table 2: Experiment results: Impacts on French market equilibria for cereals (quantities in millions of 1990 French Francs; changes in parentheses, in per cent with respect to the base)

Panel a. Common wheat

\begin{tabular}{|c|c|c|c|c|}
\hline Variables & Base year & Exp. 1 & Exp. 2 & Exp. 3 \\
\hline Domestic production $Y$ & 36,381 & $\begin{array}{l}28,631 \\
(-21.30)\end{array}$ & $\begin{array}{l}28,618 \\
(-21.34)\end{array}$ & $\begin{array}{l}24,396 \\
(-32.94)\end{array}$ \\
\hline Domestic production price $P$ & 1 & $\begin{array}{l}0.8086 \\
(-19.14)\end{array}$ & $\begin{array}{l}0.8086 \\
(-19.14)\end{array}$ & $\begin{array}{l}0.7991 \\
(-20.09)\end{array}$ \\
\hline Domestic sales of domestically produced goods $Y D$ & 18,438 & $\begin{array}{l}19,512 \\
(+5.82)\end{array}$ & $\begin{array}{l}19,503 \\
(+5.78)\end{array}$ & $\begin{array}{l}16,626 \\
(-9.83)\end{array}$ \\
\hline Exports to the RoEU $E_{R o E U}$ & 8,617 & $\begin{array}{l}9,119 \\
(+5.82)\end{array}$ & $\begin{array}{l}9,115 \\
(+5.78)\end{array}$ & $\begin{array}{l}7,770 \\
(-9.83)\end{array}$ \\
\hline Exports to the RoW $E_{R o W}$ & 9,326 & $\begin{array}{l}0 \\
(-100)\end{array}$ & $\begin{array}{l}0 \\
(-100)\end{array}$ & $\begin{array}{l}0 \\
(-100)\end{array}$ \\
\hline Composite commodity demand $X C$ & 18,739 & $\begin{array}{l}19,777 \\
(+5.54)\end{array}$ & $\begin{array}{l}19,773 \\
(+5.52)\end{array}$ & $\begin{array}{l}19,146 \\
(+2.17)\end{array}$ \\
\hline Composite commodity price $P C$ & 1 & $\begin{array}{l}0.8090 \\
(-19.10)\end{array}$ & $\begin{array}{l}0.8090 \\
(-19.10)\end{array}$ & $\begin{array}{l}0.7995 \\
(-20.05)\end{array}$ \\
\hline Intermediate consumption $C I T$ & 16,787 & $\begin{array}{l}17,825 \\
(+6.18)\end{array}$ & $\begin{array}{l}17,821 \\
(+6.16)\end{array}$ & $\begin{array}{l}17,194 \\
(+2.42)\end{array}$ \\
\hline Imports from the RoEU $M_{R o E U}$ & 233 & $\begin{array}{l}246 \\
(+5.54)\end{array}$ & $\begin{array}{l}246 \\
(+5.54)\end{array}$ & $\begin{array}{l}238 \\
(+2.17)\end{array}$ \\
\hline Imperfectly substitutable imports from the RoW $M_{R o W}$ & 68 & $\begin{array}{l}24 \\
(-64.51)\end{array}$ & $\begin{array}{l}28 \\
(-58.80)\end{array}$ & $\begin{array}{l}25 \\
(-63.01)\end{array}$ \\
\hline Perfectly substitutable imports from the RoW $S M_{R o W}$ & 0 & 0 & 0 & 2,261 \\
\hline $\begin{array}{l}\text { CIF price of perfectly substitutable imports from the } \\
\text { RoW } P S M_{R o W}\end{array}$ & 0.7582 & $\begin{array}{l}0.7911 \\
(+4.34)\end{array}$ & $\begin{array}{l}0.7911 \\
(+4.34)\end{array}$ & $\begin{array}{l}0.7991 \\
(+5.39)\end{array}$ \\
\hline
\end{tabular}


Table 2 (continued)

Panel b. Barley

\begin{tabular}{|c|c|c|c|c|}
\hline Variables & Base year & Exp. 1 & Exp. 2 & Exp. 3 \\
\hline Domestic production $Y$ & 11,373 & $\begin{array}{l}9,762 \\
(-14.16)\end{array}$ & $\begin{array}{l}9,760 \\
(-14.19)\end{array}$ & $\begin{array}{l}7,467 \\
(-34.35)\end{array}$ \\
\hline Domestic production price $P$ & 1 & $\begin{array}{l}0.8724 \\
(-12.76)\end{array}$ & $\begin{array}{l}0.8726 \\
(-12.74)\end{array}$ & $\begin{array}{l}0.7332 \\
(-26.68)\end{array}$ \\
\hline Domestic sales of domestically produced goods $Y D$ & 7,113 & $\begin{array}{l}7,329 \\
(+3.03)\end{array}$ & $\begin{array}{l}7,327 \\
(+3.00)\end{array}$ & $\begin{array}{l}5,606 \\
(-21.19)\end{array}$ \\
\hline Exports to the RoEU $E_{R o E U}$ & 2,362 & $\begin{array}{l}2,434 \\
(+3.03)\end{array}$ & $\begin{array}{l}2,433 \\
(+3.00)\end{array}$ & $\begin{array}{l}1,861 \\
(-21.19)\end{array}$ \\
\hline Exports to the RoW $E_{R o W}$ & 1,898 & $\begin{array}{l}0 \\
(-100)\end{array}$ & $\begin{array}{l}0 \\
(-100)\end{array}$ & $\begin{array}{l}0 \\
(-100)\end{array}$ \\
\hline Composite commodity demand $X C$ & 7,350 & $\begin{array}{l}7,572 \\
(+3.02)\end{array}$ & $\begin{array}{l}7,570 \\
(+3.00)\end{array}$ & $\begin{array}{l}8,006 \\
(+8.92)\end{array}$ \\
\hline Composite commodity price $P C$ & 1 & $\begin{array}{l}0.8724 \\
(-12.76)\end{array}$ & $\begin{array}{l}0.8726 \\
(-12.74)\end{array}$ & $\begin{array}{l}0.7332 \\
(-26.68)\end{array}$ \\
\hline Intermediate consumption $C I T$ & 6,115 & $\begin{array}{l}6,337 \\
(+3.64)\end{array}$ & $\begin{array}{l}6,335 \\
(+3.60)\end{array}$ & $\begin{array}{l}6,771 \\
(+10.72)\end{array}$ \\
\hline Imports from the RoEU $M_{R o E U}$ & 236 & $\begin{array}{l}243 \\
(+3.02)\end{array}$ & $\begin{array}{l}243 \\
(+3.00)\end{array}$ & $\begin{array}{l}257 \\
(+8.92)\end{array}$ \\
\hline Imperfectly substitutable imports from the RoW $M_{R o W}$ & 1 & $\begin{array}{l}0.50 \\
(-49.49)\end{array}$ & $\begin{array}{l}0.51 \\
(-49.44)\end{array}$ & $\begin{array}{l}0.22 \\
(-77.97)\end{array}$ \\
\hline Perfectly substitutable imports from the RoW $S M_{R o W}$ & 0 & 0 & 0 & 2,143 \\
\hline $\begin{array}{l}\text { CIF price of perfectly substitutable imports from the } \\
\text { RoW } P S M_{R o W}\end{array}$ & 0.7012 & $\begin{array}{l}0.7162 \\
(+2.14)\end{array}$ & $\begin{array}{l}0.7162 \\
(+2.14)\end{array}$ & $\begin{array}{l}0.7332 \\
(+4.56)\end{array}$ \\
\hline
\end{tabular}


Table 2 (continued)

Panel c. Maize

\begin{tabular}{|c|c|c|c|c|}
\hline Variables & Base year & Exp. 1 & Exp. 2 & Exp. 3 \\
\hline Domestic production $Y$ & 15,070 & $\begin{array}{l}13,698 \\
(-9.10)\end{array}$ & $\begin{array}{l}13,681 \\
(-9.22)\end{array}$ & $\begin{array}{l}10,000 \\
(-33.64)\end{array}$ \\
\hline Domestic production price $P$ & 1 & $\begin{array}{l}0.9356 \\
(-6.44)\end{array}$ & $\begin{array}{l}0.9345 \\
(-6.55)\end{array}$ & $\begin{array}{l}0.7355 \\
(-26.45)\end{array}$ \\
\hline Domestic sales of domestically produced goods $Y D$ & 5,738 & $\begin{array}{l}5,849 \\
(+1.94)\end{array}$ & $\begin{array}{l}5,842 \\
(+1.81)\end{array}$ & $\begin{array}{l}4,270 \\
(-25.58)\end{array}$ \\
\hline Exports to the RoEU $E_{R o E U}$ & 7,700 & $\begin{array}{l}7,849 \\
(+1.94)\end{array}$ & $\begin{array}{l}7,839 \\
(+1.81)\end{array}$ & $\begin{array}{l}5,730 \\
(-25.58)\end{array}$ \\
\hline Exports to the RoW $E_{R o W}$ & 1,632 & $\begin{array}{l}0 \\
(-100)\end{array}$ & $\begin{array}{l}0 \\
(-100)\end{array}$ & $\begin{array}{l}0 \\
(-100)\end{array}$ \\
\hline Composite commodity demand $X C$ & 6,144 & $\begin{array}{l}6,156 \\
(+0.20)\end{array}$ & $\begin{array}{l}6,167 \\
(+0.37)\end{array}$ & $\begin{array}{l}7,590 \\
(+23.53)\end{array}$ \\
\hline Composite commodity price $P C$ & 1 & $\begin{array}{l}0.9388 \\
(-6.12)\end{array}$ & $\begin{array}{l}0.9372 \\
(-6.28)\end{array}$ & $\begin{array}{l}0.7426 \\
(-25.74)\end{array}$ \\
\hline Intermediate consumption $C I T$ & 10,048 & $\begin{array}{l}10,060 \\
(+0.12)\end{array}$ & $\begin{array}{l}10,071 \\
(+0.23)\end{array}$ & $\begin{array}{l}11,494 \\
(+14.39)\end{array}$ \\
\hline Imports from the RoEU $M_{R o E U}$ & 77 & $\begin{array}{l}77 \\
(+0.20)\end{array}$ & $\begin{array}{l}77 \\
(+0.37)\end{array}$ & $\begin{array}{l}95 \\
(+23.53)\end{array}$ \\
\hline Imperfectly substitutable imports from the RoW $M_{R o W}$ & 329 & $\begin{array}{l}233 \\
(-29.09)\end{array}$ & $\begin{array}{l}250 \\
(-23.98)\end{array}$ & $\begin{array}{l}95 \\
(-71.24)\end{array}$ \\
\hline Perfectly substitutable imports from the RoW $S M_{R o W}$ & 0 & 0 & 0 & 3,170 \\
\hline $\begin{array}{l}\text { CIF price of perfectly substitutable imports from the } \\
\text { RoW } P S M_{R o W}\end{array}$ & 0.6919 & $\begin{array}{l}0.7067 \\
(+2.14)\end{array}$ & $\begin{array}{l}0.7067 \\
(+2.14)\end{array}$ & $\begin{array}{l}0.7355 \\
(+6.30)\end{array}$ \\
\hline
\end{tabular}


Table 2 (continued)

Panel d. Other cereals

\begin{tabular}{|c|c|c|c|c|}
\hline Variables & Base year & Exp. 1 & Exp. 2 & Exp. 3 \\
\hline Domestic production $Y$ & 5,709 & $\begin{array}{l}4,989 \\
(-12.62)\end{array}$ & $\begin{array}{l}4,984 \\
(-12.70)\end{array}$ & $\begin{array}{l}3,444 \\
(-39.67)\end{array}$ \\
\hline Domestic production price $P$ & 1 & $\begin{array}{l}0.9575 \\
(-4.25)\end{array}$ & $\begin{array}{l}0.9570 \\
(-4.30)\end{array}$ & $\begin{array}{l}0.7108 \\
(-28.92)\end{array}$ \\
\hline Domestic sales of domestically produced goods $Y D$ & 3,551 & $\begin{array}{l}3,515 \\
(-1.03)\end{array}$ & $\begin{array}{l}3,511 \\
(-1.12)\end{array}$ & $\begin{array}{l}2,426 \\
(-31.67)\end{array}$ \\
\hline Exports to the RoEU $E_{R o E U}$ & 1,490 & $\begin{array}{l}1,474 \\
(-1.03)\end{array}$ & $\begin{array}{l}1,473 \\
(-1.12)\end{array}$ & $\begin{array}{l}1,018 \\
(-31.67)\end{array}$ \\
\hline Exports to the RoW $E_{R o W}$ & 668 & $\begin{array}{l}0 \\
(-100)\end{array}$ & $\begin{array}{l}0 \\
(-100)\end{array}$ & $\begin{array}{l}0 \\
(-100)\end{array}$ \\
\hline Composite commodity demand $X C$ & 3,667 & $\begin{array}{l}3,615 \\
(-1.41)\end{array}$ & $\begin{array}{l}3,616 \\
(-1.39)\end{array}$ & $\begin{array}{l}4,120 \\
(+12.36)\end{array}$ \\
\hline Composite commodity price $P C$ & 1 & $\begin{array}{l}0.9583 \\
(-4.17)\end{array}$ & $\begin{array}{l}0.9576 \\
(-4.24)\end{array}$ & $\begin{array}{l}0.7131 \\
(-28.69)\end{array}$ \\
\hline Intermediate consumption $C I T$ & 2,408 & $\begin{array}{l}2,356 \\
(-2.15)\end{array}$ & $\begin{array}{l}2,357 \\
(-2.12)\end{array}$ & $\begin{array}{l}2,861 \\
(+18.83)\end{array}$ \\
\hline Imports from the RoEU $M_{R o E U}$ & 53 & $\begin{array}{l}52 \\
(-1.41)\end{array}$ & $\begin{array}{l}52 \\
(-1.39)\end{array}$ & $\begin{array}{l}60 \\
(+12.36)\end{array}$ \\
\hline Imperfectly substitutable imports from the RoW $M_{R o W}$ & 63 & $\begin{array}{l}49 \\
(-22.69)\end{array}$ & $\begin{array}{l}53 \\
(-16.55)\end{array}$ & $\begin{array}{l}14 \\
(-78.57)\end{array}$ \\
\hline Perfectly substitutable imports from the RoW $S M_{R o W}$ & 0 & 0 & 0 & 1,629 \\
\hline $\begin{array}{l}\text { CIF price of perfectly substitutable imports from the } \\
\text { RoW } P S M_{R o W}\end{array}$ & 0.6625 & $\begin{array}{l}0.6766 \\
(+2.13)\end{array}$ & $\begin{array}{l}0.6766 \\
(+2.13)\end{array}$ & $\begin{array}{l}0.7108 \\
(+7.29)\end{array}$ \\
\hline
\end{tabular}


Table 3: Experiment results: Impacts on selected variables (quantities in millions of 1990 French Francs; changes in parentheses, in per cent with respect to the base)

\begin{tabular}{lcccc}
\hline Variables & Base year & Experiment 1 & Experiment 2 & Experiment 3 \\
\hline Land use for COP crops & 17,502 & 16,401 & 16,398 & 15,375 \\
& & $(-6.29)$ & $(-6.31)$ & $(-12.15)$ \\
Value added in the sector of COP crops & 50,651 & 32,819 & 32,782 & 23,457 \\
& & $(-35.20)$ & $(-35.27)$ & $(-53.69)$ \\
Domestic production & & & & \\
Pork & 19,969 & 20,544 & 20,547 & 21,028 \\
& & $(+2.88)$ & $(+2.89)$ & $(+5.31)$ \\
Poultry & 25,013 & 25,603 & 25,607 & 26,224 \\
& & $(+2.36)$ & $(+2.38)$ & $(+4.84)$ \\
Beef & 46,984 & 50,159 & 50,169 & 52,658 \\
& & $(+6.76)$ & $(+6.78)$ & $(+12.08)$ \\
Equivalent Variation) & & & & \\
\hline
\end{tabular}




\section{Working Papers INRA - Unité ESR Rennes}

02-01 Tariff protection elimination and Common Agricultural Policy reform: Implications of changes in methods of import demand modelling. Alexandre GOHIN, Hervé GUYOMARD and Chantal LE MOUËL (March 2002) 